\title{
SDS 存在下におけるコイ筋原繊維たんぱく質 のゲル汇過と電気泳動*1
}

\author{
関伸夫・新并健一 \\ (1974 年 8 月 7 日受理)
}

\author{
Gel Filtration and Electrophoresis of Fish Myofibrillar Proteins \\ in the Presence of Sodium Dodecyl Sulfate \\ Nobuo SeKI*2 and Ken-ichi AraI*2
}

\begin{abstract}
A gel filtration method in the presence of sodium dodecyl sulfate (SDS) was applied to the separation of the components of myofibrillar proteins from fish muscle. A characterization of the components obtained by gel filtration chromatography was made by measuring the mobilities on SDS-polyacrylamide gel electrophoresis.

Gel filtration of carp myosin gave two clearly separated peaks, corresponding to myosin heavy chains and light chains. The weight ratio of heavy chains to light chains of myosin was estimated to be approximately $87: 13$, while carp actin gave a single peak which was eluted between the peaks of myosin heavy chains and light chains.

Actomyosin was separated into three peaks. The weight ratio of myosin to actin in actomyosin prepared by the ordinary method was estimated to be approximately $3: 1$.

Myofibrils, accounting for $70 \%$ of the muscle proteins, were completely dissolved in SDS. The elution pattern of dissolved myofibrils was closely similar to that of actomyosin.

The present method was successfully used to examine the purity of myosin, actin, and actomyosin and to estimate the contents of their respective components.
\end{abstract}

魚肉構成たんぱく質の研究が困難である理由は幾つかあるよらに思われる。その一つとして魚肉からのた んばく質の抽出性，溶解性がウサギ骨格筋の場合の上うに良く知られて㧍らず不明な点が多いことである。 例克ば魚肉からの筋形質たんばく質や筋原瀻維たんばく質の抽出法, 調製法について研究者に上り各種の異 なる方法が提案されている1)。それは魚肉を溶解むたは抽出して得たたんばく質が，ミオシン，フタチンあ るいはそれ以外のたんばく質成分から成るのかどらかについて適当な判定の手段を持ななかつたことによる。 著者らの研究室では，先に生物活性を測定し，ミオンン，アクチン，アクトミオンンの特性を表わすことを 研究したが，これらの成分を定量的に表わすことは，ほとんど不可能であつた2)。一方魚肉を原料とした加

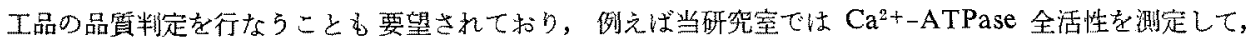
冷凍すり身をアクトミオシンとみなし，その品質を判定する方法を報告しだ。。しかし，それを構成してい る魚肉たんばく質の組成については皘極的な研究はまだ行なわれていない。

最近，高分子たんばく質や不溶性たんばく質をSDS で処理して可溶化すると同時に，サブニニットに分

*1 SDS: sodium dodecyl sulfate

*2 北海道大学水産学部生物化学教室 (Laboratory of Biochemistry, Faculty of Fisheries, Hokkaido University, Hakodate, Japan) 
けて電気泳動などの方法で分析して, それらのサブュニット掼造や純度を明らかにする技術が発展している。 この方法によれば, 筋原䋐維たんぱく質, 変性して一部不溶化の進んだたんぱく質です, あるいは魚肉との あの，魚肉の加工品䎲つててもある程度の研究が可能であると考光られる。


魚肉加工品の一例として，冷湅すり身の構成たんぱく質をSDS に上つて可溶化し，それの構成を知ると同 時に各成分の簡便な定量法を確立することを目的とした。

\section{実 験 方 法}

ミオシンの調製4) コイ筋肉から $5 \mathrm{~mm} \mathrm{ATP-1} \mathrm{mM} \mathrm{MgCl}_{2}$ を含む $0.45 \mathrm{M} \mathrm{KCl}(\mathrm{pH}$ 6.4) で5分間

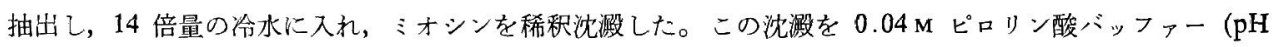
7.5) に溶解後，DEAE-Sephadex A-50 クロマトグラフィーによつて精製した。すなわち稀积沈澱で得た ミオシンおよそ 150 200 mg を $\phi 2.2 \times 25 \mathrm{~cm}$ の DEAE-Sephadex A-50 カラムに供した。カラムから たんばく質の溶出は stepwise elution によつて行ない, $15 \mathrm{ml}$ ずつを分取し， $280 \mathrm{~m} \mu$ の吸光值を測定し た。まず $0.04 \mathrm{M}$ ピロリン酸バッファー ( $\mathrm{pH} 7.5)$ で溶出される区分を捨て, 溶媒を $0.25 \mathrm{M} \mathrm{KCl}-0.04 \mathrm{M}$

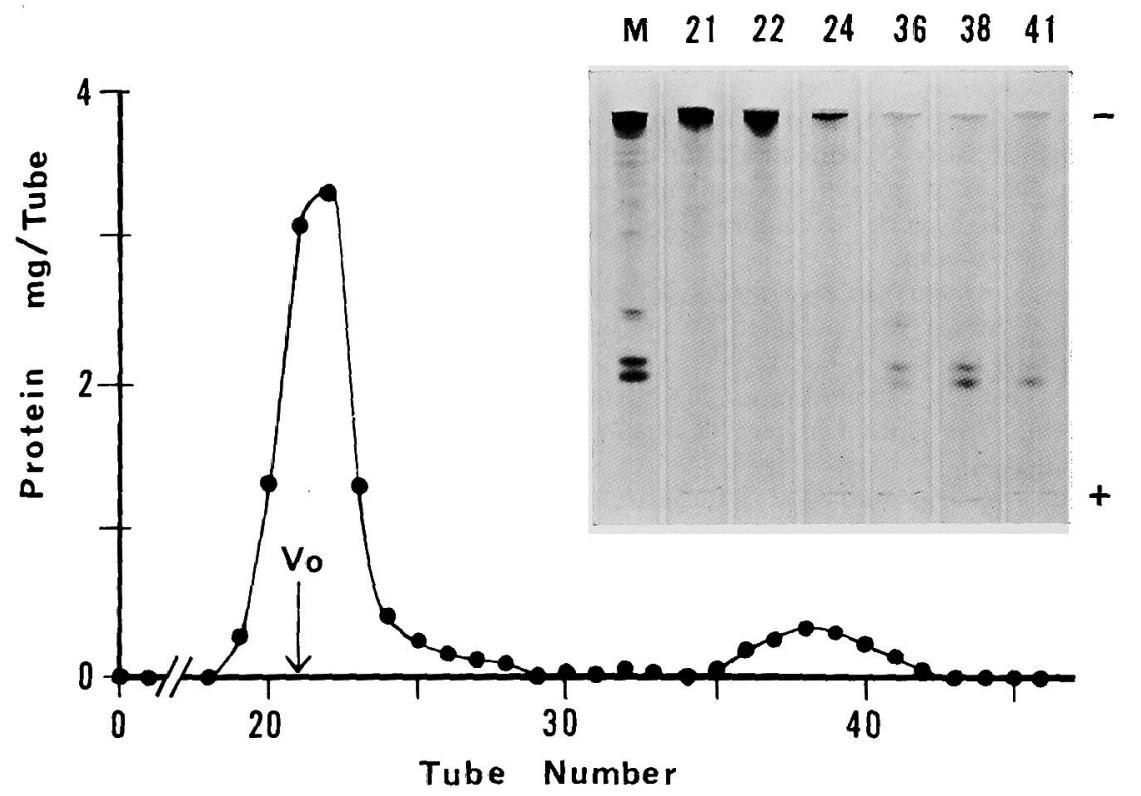

Fig. 1. Sephadex G-200 gel filtration of myosin in the presence of SDS.

Myosin from carp muscle was incubated in 1\% SDS-1\% 2-mercaptoethanol- $5 \mathrm{~mm}$ phosphate buffer ( $\mathrm{pH} 7.2$ ) at room temperature overnight. Five milliliters of myosin $(12.8 \mathrm{mg})$ were applied to a column $(2.2 \mathrm{~cm} \times 90 \mathrm{~cm})$ of Sephadex G-200 equilibrating with $0.1 \%$ SDS- $5 \mathrm{~mm}$ phosphate buffer (pH 7.2). The protein was eluted with the same solution at room temperature and 4.8 milliliters fractions were collected. Void volume (Vo) indicated by the arrow determined by using Blue Dextran 2000. Protein was determined by the micro-biuret method.

The inserted figures are the SDS-polyacrylamide gel electrophoretic patterns of the indicated tube numbers and the original myosin $(M)$ used for gel filtration. SDSpolyacrylamide gel electrophoresis were performed according to WEBER and OSBORN ${ }^{13)}$ using $0.1 \%$ SDS- $10 \%$ gels. 
ピロリン酸バッファー ( $\mathrm{pH}$ 7.5) に変えて溶出されるミオシンを集めた。これを $\mathrm{H}_{2} \mathrm{O}$ に透析後, 生じた沈 澱を遠心分離によつて集め, $0.6 \mathrm{M} \mathrm{KCl}-20 \mathrm{mM}$ Tris-maleate $(\mathrm{pH}$ 7.5) に浴解させた。

アクチンの調製) コイひき肉を $0.4 \% \mathrm{NaHCO}_{3}$ で洗浄したのち, アセトンパウダーとした。これか ら G-アクチンを $0.5 \mathrm{~mm} \mathrm{ATP-2} \mathrm{mM} \mathrm{Tris-} \mathrm{HCl}$ (pH 8.0)-0.5 mM 2-メルカプトェタノール-0.2 mM $\mathrm{CaCl}_{2}$ で抽出した。抽出液に $0.1 \mathrm{M} \mathrm{KCl}-1 \mathrm{mM} \mathrm{MgCl}$ 濃度となるように $\mathrm{KCl}-\mathrm{MgCl}_{2}$ 混液を加光重合さ

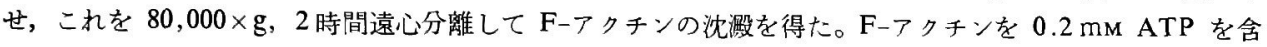
む前述のバッファーで透析脱重合して G-アクチンを得た。

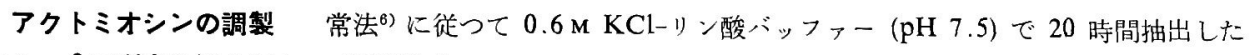
のち, 3 回稀积沈澱を行なつて精製した。

筋原紪維の調製 コイひき肉を 5 倍量のリン酸バッファー $(I=0.05, \mathrm{pH} 7.5)$ で 3 回洗浄後, 同バ ッファーを加えて日本精機製ユニバーサルホモジナイザー HB 型（回転目盛 2.5, 約 6,000 rpm) を用い て1分間ずつ 3 回ホモジナイズした。ホモジネートを一層のガーゼを通して沪過し, 沪液を遠心分離して沈 澱を集め, 沈澱をさらに 3 回，15 倍量の同バッファーで洗浄した。ここで得られるたんばく質は魚肉の全 たんぱく質の打よそ70\%に相当する。ここで述べた調製方法は, 従来の方法7,8)とは異なつており，得られ たものについて形態学的観察や生理活性についての検討は加えていないが，筋原繊維たんぱく質を筋形質た んぱく質から分画することを主目的としたものである。

筋原織維たんぱく質の可溶化 塩溶液として得られたアクトミオシン，ミオシンは $\mathrm{H}_{2} \mathrm{O}$ に透析して脱 塩したが，同時に不溶化するのでひき続き $0.1 \%$ SDS-5 mM リン酸バッフー（pH 7.2)に室温で透析し て, 再溶解させた。筋原繊維は $8 \mathrm{M}$ 尿素- $1 \%$ SDS- $1 \%$ 2-メルカプトエタノール-10 mM リン酸バッファー



Fig. 2. Sephadex G-200 gel filtration of actin in the presence of SDS.

Five milliliters $(14.6 \mathrm{mg})$ of partially purified actin by reversible polymerization were applied to a column.

The inserted figures are the SDS-polyacrylamide gel electrophoretic patterns of the indicated tube numbers and the original actin $(A)$.

Other experimental conditions were same as in Fig. 1.

The purity of this actin preparation was easily estimated at $86 \%$ from the area of elution pattern. 
(pH 7.2) または 5\% SDS で可溶化したのち，0.1\% SDS-5 mM リン酸バッファー（pH 7.2）に透析し た。可溶化扰よび透析は室温で行なつた。透析後たんばく質量をビウレット法あるいはミクロビウレット法 により求めた。1\% 以下の SDS の存在は発色には影響を与えないことを確かめた。

SDS-ゲル沪過試料はゲル沪過に供する前に SDS 処理を行なつた。すなわち試料に SDS と2ーメル カプトエタノールを終濃度がそれぞれ $1 \%$ になるよらに加克，室温に一夜インキュベートした。Sephadex

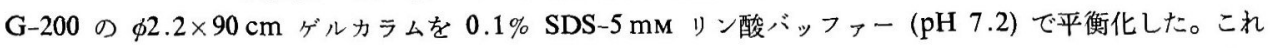
に SDS 処理をしたたんぱく質 $5 \mathrm{ml}(10 \sim 30 \mathrm{mg})$ をゲルの上端に入れ, 平衡化に用いたバッフォーで容出 した。 $5 \mathrm{ml}$ をフラクションコレクターで分取し, 各画分中のたんばく量をミクロビウレット法によつて測 定した。なおたんばく質のゲルカラムからの回収率は，たんぱく質の種類によらず 90 95\% であつた。

SDS-ポリアクリルアミドゲル電気泳動は, 前報らに述べた通り $10 \%$ アクリルアミド-0.1\% SDS ゲルカ ラムを使用して行なつた。

\section{実 験 結 果}

ミオシンのゲル沪過ＤEAE-Sephadex A-50 カラムクロマトグラフィーで精製したコイのミオシン のSDS-ゲル汇過図をFig. 1 に示した。Fig. 1 中の写真はゲル洰過によつて得た各画分のSDS-ポリアク リルアミドゲル電気泳動図である。また M はゲル沪過に供する前のミオシン原試料の電気泳動図である。 ミオシンの SDS-ポリアクリルアミドゲル電気泳動では, ミオシンは分子量 20 万程度の heavy chain と 分子量が 1 2 万程度の数本の light chain と呼ばれる成分に解離することが知られている

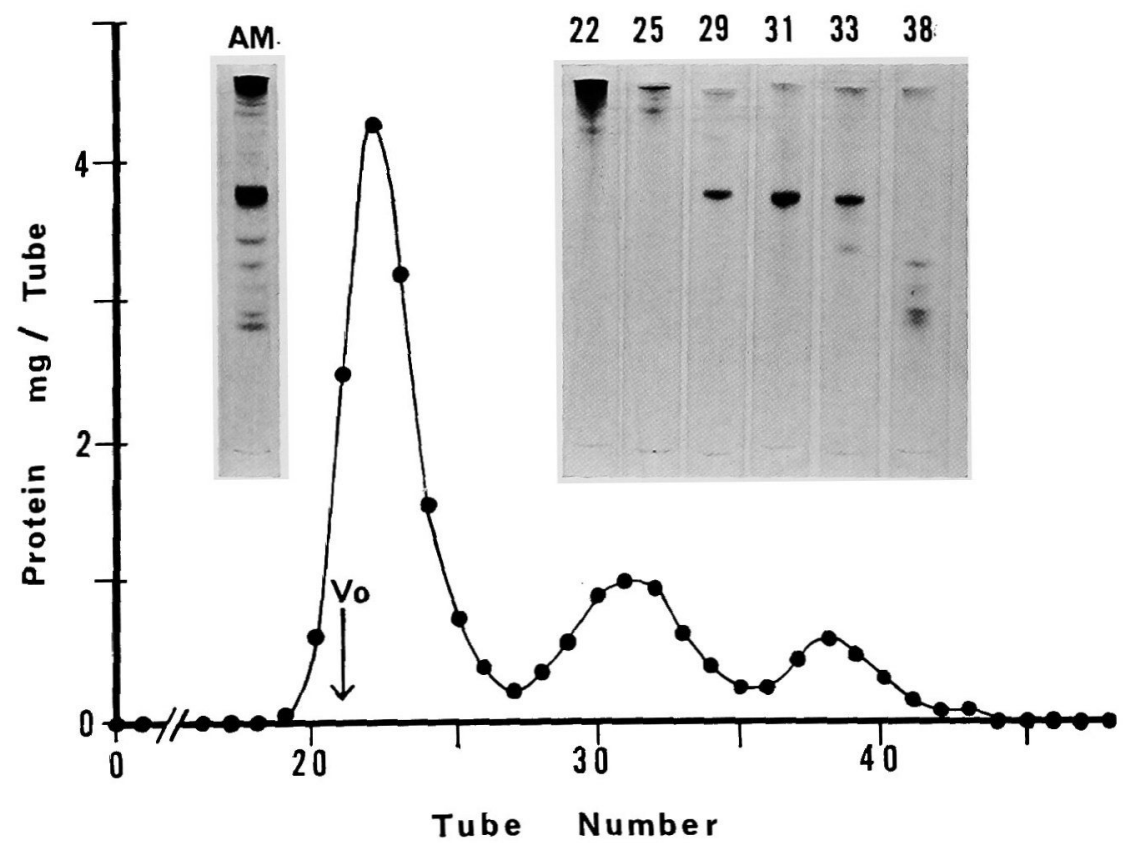

Fig. 3. Sephadex G-200 gel filtration of actomyosin in the presence of SDS. Five milliliters $(21.2 \mathrm{mg})$ of actomyosin were applied to a column.

The inserted figures are the SDS-polyacrylamide gel electrophoretic patterns of the indicated tube numbers and the original actomyosin $(A M)$.

Other experimental conditions were same as in Fig. 1. 
ミオシンの SDS-ゲル沪過図では void volume 付近に大きなピークと,かなり遅れて溶出される小さなピ

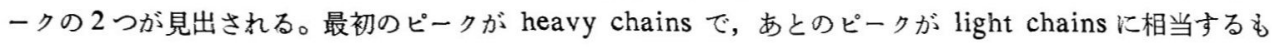
のであつた。したがつて SDS 存在下では, ゲル沪過によるミオシン成分の溶出順序と SDS-ポリアクリル アミドゲル電気泳動におけるをれらの移動順序は全く同じで，分子量の順に従つていることが示されてい る。また Fig. 1 の結果から, 最初のピークと後ろのピークのたんぱく質量を定量すると, コイミオシンの heavy chains と light chains の量を概算することができる。それによると両者の比率はそれぞれ $87: 13$ であつた。

アクチンのゲル沪過＼cjkstart重合一脱重合を一回行つて精製したアクチンのゲル沪過図が Fig. 2 である。眓 中の写真は Fig. 1 の場合と同様に A がダル沪過前のアクチン原試料で, アクリルアミドゲルの上に記し た数字はゲル沪過によつて得られた各画分の番号である。アクチンのピークは void volume の位置よりか なり遅れて溶出されるが，この位置はミオシンの heavy chains や light chains とは重ならない。Fig. 2 ではアクチンのピークの後ろに小さな 2 つのピークが見出されるので，アクチン以外のたんぱく質が混入し ていることがわかる。これらはトロポニンのサブニニットや，ミオシンの light chains の混合物であると 思われる。前報らで報告したように, アセトンパウダーより抽出したアクチンを重合脱重合で精製した標品 には, まだ少量のトロポニン，トロポミオシンが混入しており，これらは通常の Sephadex G-200 による

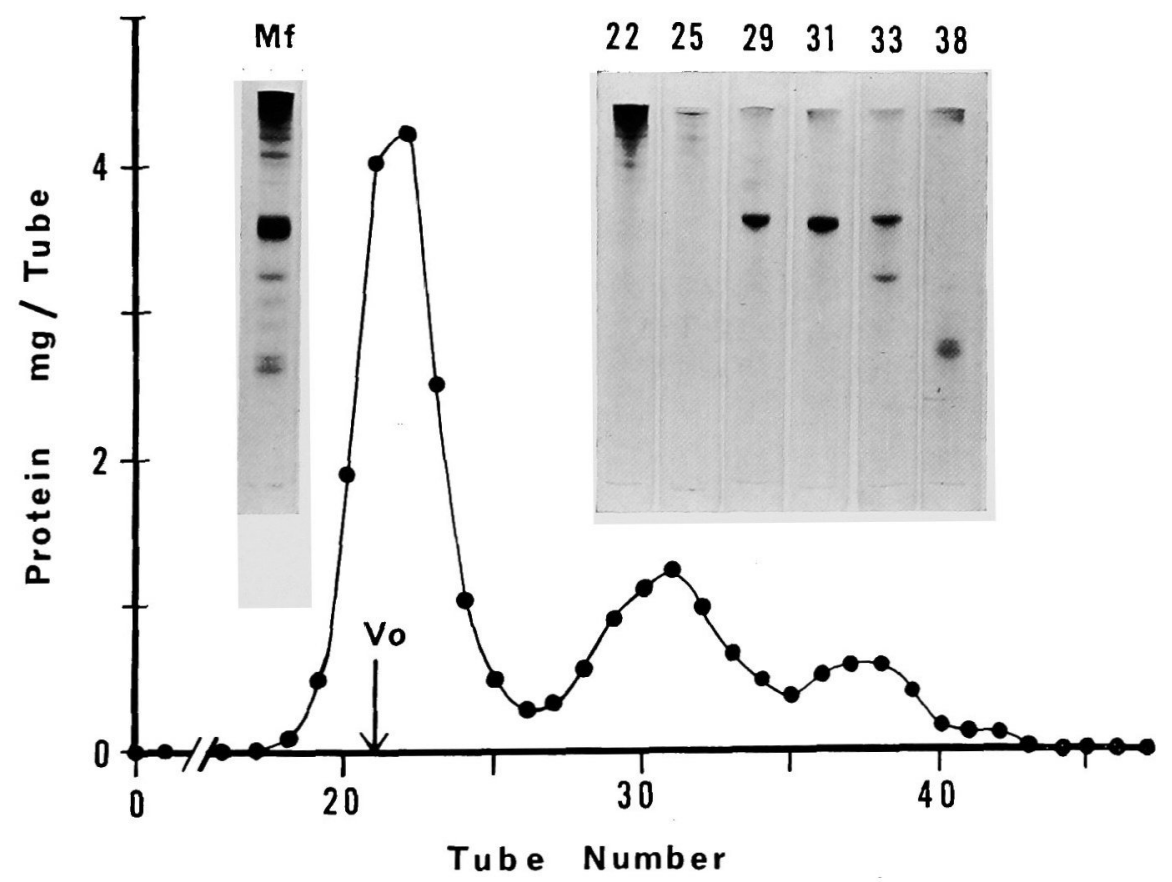

Fig. 4. Sephadex G-200 gel filtration of myofibrils in the presence of SDS. Myofibrils were roughly prepared by washing the muscle exhaustively with phosphate buffer $(I=0.05, \mathrm{pH} 7.5)$ and then dissolved in $8 \mathrm{M}$ urea-1\% SDS- $1 \%$ 2-mercaptoethanol-10 mM phosphate buffer ( $\mathrm{pH} 7.2)$.

Five milliliters $(25.4 \mathrm{mg})$ of the sample were applied to a column.

The inserted figures are the SDS-polyacrylamide gel electrophoretic patterns of the indicated tube numbers and the dissolved myofibrils $(M f)$.

Other experimental conditions were same as in Fig. 1. 


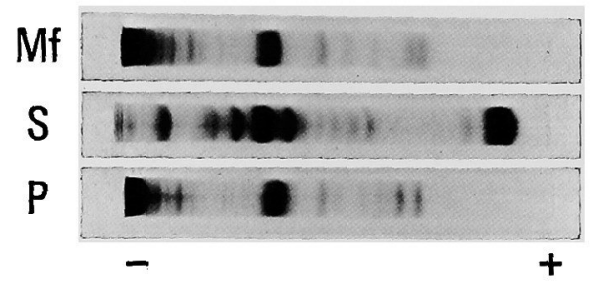

Fig. 5. SDS-polyacrylamide gel electrophoresis of myofibrils $(M f)$ and sarcoplasmic proteins ( $S$ ) from carp, and "surimi" from Alaska pollack $(P)$.

"Surimi" was dissolved in $8 \mathrm{M}$ urea$1 \%$ SDS-1\% 2-mercaptoethanol-10 m phosphate buffer ( $\mathrm{pH} 7.2$ ).

SDS-polyacrylamide gel electrophoresis were performed according to WEBER and OSBORN ${ }^{13)}$.
ゲル沪過ではトロポニンートロポミオシン複合 体として G-アクチンのピークより早く void volume 付近に溶出される。ところが SDS-ゲ ル汇過では，これらは各々のサブニニットに解 離するので, アクチンのピークよりは遲れて溶 出されることが示されている。しかしコイのト ロポニンは現在まで純粋に単離されていないの でそのサブニニットの位置についての詳細は まだ断定できない。ここで用いたアクチン試料 の純度は各々のピークのたんぱく量を測定して 簡単に概算できる。それによるとおよそ $86 \%$ となる。

アクトミオシンのゲル沪過アクトミオシ ンの SDS-ゲル沪過では, Fig. 3 に示すように 3つのピークが得られる。これらのピークはミ オシンとアクチンそれぞれのゲル汇過図，およ

び Fig. 3 中に插入した SDS-ポリアクリルアミドゲル電気泳動図から, 最初のピークがミオシンの heavy chains, 次のピークがアクチン, 最後のピークがミオンンの light chains であることが明らかである。す なわちアクトミオシンはSDS 存在下ではミオシン heavy chains, light chains およびアクチンK解離し ているので，そのゲル沪過図はミオシンとアクチンを合わせたものになる。しかるアクチンとミオシンは重 なつて溶出されないので,アクトミオシン中のアクチンとミオシンの量を求めることが可能である。Fig. 3 のゲル沪過図からここで用いたアクトミオシン中のアクチンとミオシンの比率を概算してみた。ミオシン 量はミオシンの heavy chains 含量から算出すると, ミオシン量=ミオシン heavy chains $\times 100 / 87$ であ りアアクチンとミオシンの比率は，およそ $1: 3.3$ となる。ミオシン量はミオシンの heavy chains と light chains の合計量で求められるのであるが，アクトミオシンの場合には light chains の画分にはトロ ポニンなどが混在するので，ミオシン heavy chains の量から算出した。しかし注意を要することは，徒 来の方法 ${ }^{8)}$ で調製したアクトミオシンにはトロポニンやトロポミオシンが存在するのが普通であることであ る。特にトロポミオシンは SDS-ゲル沪過ではアクチンのピークと重なるので, 常法で得たアクトミオシン のゲル汇過で得られるアクチンのピークにはトロポミオシンが含まれる。本実験で用いたフクトミオシンは 調製に当り稀釈沈澱をくり返して精製して，トロポミオシンを除去した。すなわち SDSーポリアクリルアミ ドゲル電気泳動ではトロポミオシンのバンドはフクチンよりやや移動が早いので検出が容易であるにもかか わらず見出されていない。

筋原緎維たんぱく質のゲル汇過万法の項で述べたように本実験で用いた筋原瀻維は, 低イオン強度り ン酸バッフーで筋肉を洗浄して，徽底的に水溶性成分を除いて得られる残渣であるが，筋肉の全たんばく 質のおよそ $70 \%$ に相当する。これを SDS で可溶化すると基質たんぱく質と考えられるものを除いて，す ベて可溶化される。コイ背筋の場合はSDS で可溶化されないたんぱく質量は筋原䋐維の $1 \%$ 以下である。 筋原緎維たんぱく質のゲル沪過図を Fig. 4 に示した。最初のピークがミオシンの heavy chains, 次がア クチンのピークである。この結果とアクトミオシンのゲル沪過で得られた結果 (Fig. 3) を比較してみると, 両者は極めて良く似ており，それぞれの図中に挿入した SDS-ポリアクリルアミドゲル電気泳動図も似てい る。これらの結果は魚の筋原絨維の大部分を占めるたんばく質がフクトミオシンであることを示している。 ここで用いたュイ筋原㵶維中のアクチンとミオンンの比率はおよそ $1: 2.8$ である。別に調製したアクトミ

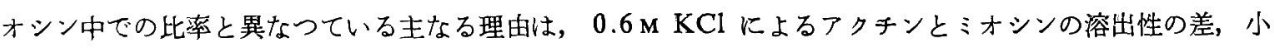
胞体由来のたんぱく質成分の混入の問題や水溶性たんばく質の残存量の違いなどが考えられる。 
考察

本実験ではかなり精製されたミオシン，アクチンンアクトミオシンを用いたので，それらのサブユニット に関する SDS-ゲル沪過およびポリアクリルアミドゲル電気泳動図は確立できた。したがつてこれを摽準と して，今後抽出溶解したたんばく質の組成を知り，純度を推定して行くことが容易になるであるう。ただし 魚種によつてミオシンの light chains の組成 ${ }^{11} に は$ 差があるので注意が必要である。またトロポニンにつ いてもその純粋なものについてサブニニットが発表されていないので，比較生化学的に異なることも考虑し ておく必要がある。また本方法によつて各たんばく䝯成分の精密な定量を行ならための配慮はしていないの で，本実験で得られた值はあくまでも概算值といわねばならないが，魚肉たんばく質の耔出性，溶解性にお ける疑問点を整理するためには極めて有効な方法であるといえる。特に SDS による筋原瀻維や，変性たん 价質の可溶化と，SDS 存在下に和けるゲル汇過と電気泳動の組合わせにより，各構成たんばく留成分の 䉮便な定量やサブュニットの検策に役立てることができる。

SDS 存在下に括いて，ミオシンは heavy chains と light chains と呼ばれる部分に分かれる。ミオシ ン heavy chain は分子量が 22 万と大きく，゙ル沪過では void volume 付近に溶出される。10\%ゲル を用いた SDSーポリアクリルフミドゲル電気泳動では，ゲルの中に少し入るだけであるが，このミオシン heavy chains K相当するものは分子量的にも量的にも，筋形質たんぱくには存在しないのでこのものは ミオシンを含む筋原繊維たんぱく質の特徵となるものである。参考のために，Fig. 5 Kュイの筋肉から低 イオン強度りン酸バッフォー（I=0.05, pH 7.5) で溶出されるたんぱく揗のSDS-ポリアクリルアミドゲ ル電気泳動因 (S) を示した。图から明らかなように：ミオシンの heavy chains に相当するもの蚛出さ れず，筋原絨維と筋形質たんぱく質との間には明瞭な差がある。しかし，アクチンのバンドにはそれに相当 する位置にバンドが見出されている。これは解糖系酵素（アルドラーゼなど）やクレアチンキナーゼのサブ ユニットがアクチンに近い分子量をるつためであろ ${ }^{12,13)}$ 。さらに魚肉の場合は次の点の考慮も必要之思わ れる。すなわち魚肉のフクチン，トロポミオシンは筋原緎雅やフクトミオシンを水あるいは低イオン強度の パッファーに晒しておくと，一部溶出され易いので，これらのたんばく質が水溶性区分に混入している可能 性も考えなければならない。アクトミオシンのゲル沪過図 (Fig. 3) から，アクチンとミオシンの此率は拉 よそ 1:3であり：ミオシン heavy chains は分子量が大きいだけでなく量的にも多いことが示される。 Fig. 3 のパターンをアクトミオシン型と呼ぶことにすると，筋原絨維たんばく質のパターンるまたアクト ミオシン型を示す。これは筋原緘維はフクトミオシンそのものであることの一つの証拠である。すなわら， SDS-ゲル沪過あるいは SDS-ポリアクリルアミドゲル電気泳動図がミオシンやアクトミオシン型のパタ一 ンを示すことは，そのたんぱく質試料が筋原繊維たんぱく質に由来していることを予想させるものである。

Fig. 5 中の写真 P は，スタトウダラ冷凍すり身を直接 SDS で叮溶化して, SDS-ポリアクリルアミド ゲル電気泳動に供したときの図である。ここには示さなかつたが，SDS-ゲル沪過の図もアクトミオシン型 を示していた。この事央は魚肉を水晒して製造したすり身では，水溶性たんばく質は除去されており，アク トミオシンが主成分であることを示している。このようにして，本方法はすり身などの魚肉加工品のたんぱ く質成分の推定や，添加した異種たんぱく質の検出など，品質の判定面にも広く応用できるので，この点に ついてす現在検討を続けている。

本研究の遂行にあたり御協力をいただいた横山和博君に深く感謝致します。

\section{文献}

1) 志水 寛: New Food Industry, 12, 4-8 (1970).

2) 新井健一: 同誌, 12, 15-18 (1970).

3）川島省・大場明子・新井煡一：本誌，39，1201-1209 (1973).

4) 高士令二: 同誌, 38, 126-132 (1972). 
5) 関伸夫・北尾 腾 - 今野久仁彦・新井健一：同誌, 39, 1211-1219 (1973).



7) S. V. Perry and T. C. Grey: Biochem. J., 64, 184-192 (1956).

8) 常盤知宣・松宫弘幸: 本誌, 35, 1099-1109 (1969).

9) B. Paterson and R. C. Strohman: Biochemistry, 9, $4094-4105$ (1970).

10) A. G. WeEDS and S. LoweY: J. Mol. Biol., 61, 701-725 (1971).

11) 高士令二・室塚刷志 - 新井健一：本誌，40，1155-1161 (1974).

12) R. K. Scopes and I. F. Penny: Biochim. Biophys. Acta, 236, 409-415 (1971).

13) K. Weber and M. Osborn: J. Biol. Chem., 244, 4406-4412 (1969). 